\title{
KMETIJSKO OBREMENJEVANJE SLOVENSKEGA ALPSKEGA SVETA NA IZBRANEM PRIMERU
}

\author{
Darko Radinja*
}

Izvleček

UDK 911.3:504.05=863(497.4-924.43)

Poročilo obravnava energijsko intenzivnost kmetijstva v dolinskih Ratečah $(860 \mathrm{~m})$ kot osnovo za presojo obremenjevanja alpskega okolja. Zaradi (sub)urbane preobrazbe kmečkega naselja je agrarno obremenjevanje ostalo sicer zelo zmerno, povečalo pa se je neagrarno. Skupno obremenjevanje okolja še ni pretirano, še največ pa ga je zaradi pomanjkljive komunalne infrastrukture naselja.

Ključne besede: Agrarno obremenjevanje pokrajine, energijska intenzivnost kmetijstva, alpsko naselje, Zgornja Savska dolina.

A CASE STUDY OF AGRICULTURAL POLLUTION IN SLOVENIAN ALPINE WORLD

\section{Abstract}

The paper discusses the energy intensity of agriculture in the valley location of Ratece $(860 \mathrm{~m}$ above sea level) as a basis for assessing pollution in the Alpine environment. Owing to the transformation of a rural settlement into a (sub)urban settlement, the agrarian pollution continues to be tolerable, while the nonagrarian pollution has increased. The hitherto total environmental pollution has not been excessive, and most of it resulted from the deficient utility infrastructure of the settlement.

Key words: Agrarian environmental pollution; Energy intensity of agriculture; Alpine settlements; the Upper Sava valley.

\footnotetext{
* Dr., prof., v pokoju, Oddelek za geografijo, Filozofska fakulteta Univerze v Ljubljani, Aškerčeva 2, SI 1000 Ljubljana, Slovenija
} 


\section{IZHODIŠČE}

$\mathrm{V}$ okviru katedre za pokrajinsko ekologijo in varstvo geografskega okolja potekajo $\mathrm{v}$ zadnjih letih raziskave, ki skušajo kmetijsko obremenjevanje okolja opredeliti s prikazom energijske intenzivnosti našega kmetijstva (Radinja, 1990, 1991, 1992, 1993, 1994, 1995, 1996; Rejec Brancelj, 1994; Lampič 1995; Smrekar, 1995; Urbanc, 1996; Sitar, 1996). Dosedanje ugotovitve kažejo, da tovrstnega obremenjevanja ruralnih pokrajin ne kaže več zanemarjati. Da bi prišli do določnejšega pregleda glede njegovih stopenj in značilnosti ter do pokrajinskih razlik, se raziskovanja usmerjajo $\mathrm{v}$ posamezne pokrajinske tipe. Doslej so bile $v$ ospredju prodne ravnine, zlasti subpanonske, ki postajajo zaradi intenzivnejšega kmetijstva in občutljivih naravnih osnov že preobremenjene, bržkone najbolj med slovenskimi pokrajinami.

Tokrat je raziskovanje seglo $\mathrm{v}$ alpski dolinski svet, $\mathrm{v}$ Zgornjo Savsko dolino, in sicer $\mathrm{v}$ Rateče, ki so $v$ njej najvišje in tudi najbolj alpske. Tu naj bi šlo za drugačen tip obremenjevanja okolja, ki pa ni posledica intenzivnosti kmetijstva, kakor na subpanonskih ravninah, temveč značilne deagrarizacije, predvsem pa večje občutljivosti alpske pokrajine. Raziskava se hkrati dopolnjuje z drugim projektom (Pokrajinska struktura in problematika severozahodnega alpskega sveta Slovenije), ki na Oddelku za geografijo FF poteka $v$ okviru katedre za fizično geografijo. Pri raziskavi so leta 1993 na terenskih vajah sodelovali tudi študenti geografije. Iz takrat nastalega poročila (Radinja, 1994) so tokrat povzete poglavitne ugotovitve.

\section{METODOLOŠKE OSNOVE}

Agrarno obremenjevanje okolja je mogoče ugotavljati na različne načine. Najbolj znane, a hkrati najzahtevnejše in najzamudnejše so meritve dejanske onesnaženosti posameznih členov agrarnega okolja (analize voda, prsti, kulturnih rastlin itd.), kar pa je domena različnih strok, medtem ko je $\mathrm{v}$ ospredju geografskega preučevanja njihovo pokrajinsko součinkovanje.

Načelno povsem drugačne metodologije so se oprijeli nekateri drugi avtorji, med njimi najbolj celovito in določno Slesser (1975), ki na agrarno onesnaževanje okolja sklepa po energijski intenzivnosti samega kmetijstva, kar opredeljuje $\mathrm{z}$ energijskimi ekvivalenti. To omogoča, da različne snovi in oblike energije, vložene v kmetijstvo, izrazimo enotno, navadno $v$ giga joulih na hektar obdelovalne zemlje (GJ/ha ). S tem je $v$ razmeroma enostavni obliki mogoče izraziti ne le intenzivnost posameznih kmetij, temveč kmetijstva sploh ter ga med seboj tudi primerjati. Po energijski intenzivnosti je Slesser razvrstil kmetijstvo na več stopenj ter postavil, da kmetije, ki porabijo letno 
manj kot 15 GJ energije na hektar kulturne površine, okolja še ne onesnažujejo oziroma, kakor pravi avtor, onesnaževanje se izven kmetije še ne širi.

Po tej metodi sicer ni mogoče neposredno ugotavljati dejanske onesnaženosti okolja, pač pa potencialno (obremenjenost), kajti prva je odvisna tudi od občutljivosti samega okolja (njegove samočistilne sposobnosti). Manj ugodna stran metode je ta, da je podatke o energijski intenzivnosti kmetij mogoče dobiti le s terenskimi raziskavami (anketiranjem). Metoda je sicer koncepcijsko bližja geografskemu načinu raziskovanja, vsekakor bolj kakor kemijske in druge analize posameznih členov onsenaženega okolja, saj izhaja pravzaprav iz agrarnogeografskih študij (Pimental, 1973; Leach, 1973). Vsekakor pa dosedanje metode koristno dopolnjuje. Za enoličnejše naravnogeografske razmere je Slesserjeva metoda ustreznejša, kakor za pokrajinsko pestre, kakršne so v Sloveniji. Zato je omenjeni prag še dopustnega obremenjevanja agrarnega okolja za slovenske razmere slej ko prej orientacijski in ga je za posamezne pokrajine mogoče potrditi šele s primerjavo njihove stvarne onesnaženosti, vsaj glede voda. To povezavo naše raziskave povečini tudi že ugotavljajo. Ker se hkrati kritično dotikajo metodološke problematike tovrstnega raziskovanja, je Slesserjeva metoda za pestro pokrajinsko strukturo Slovenije ustrezno prirejena.

\section{ZNAČILNOSTI RATEŠKE POKRAJINE}

\section{3.l. Reliefne osnove}

Med naravnimi osnovami, pomembnimi za gospodarsko, zlasti kmetijsko rabo, je odločilna trojna sestava Rateške pokrajine, kakor se je na stiku Julijskih Alp in Karavank izoblikovala v vmesni Zgornji Savski dolini. Pokrajina se pravzaprav ujema $\mathrm{z}$ obsegom precej velike katastrske občine $\left(50,8 \mathrm{~km}^{2}\right)$, ki pa je bila po prvi svetovni vojni razpolovljena z državno mejo. Najpomembnejši je seveda njen osrednji, najnižji, dolinski del, čeprav je najmanjši. Drugi po velikosti je na severni strani karavanški del, medtem ko tretji, daleč najobsežnejši, pripada Julijskim Alpam. Medtem ko dolinski svet (dno glavne doline) ne obsega niti desetine celotne pokrajine $(6 \%)$, zavzema karavanški približno četrtino (24\%), julijski pa več kot dve tretjini (70 \%).

Potemtakem pripada Rateški pokrajini približno pet kilometrov dolg odsek Zgornje Savske doline s pripadajočimim pobočji Karavank in Julijskih Alp. Medtem ko so prva pobočja (karavanška) krajša in sklenjena, so druga (julijska) obsežnejša in močno razčlenjena, saj sta se v njih izoblikovali dve globoki, stranski dolini, Planiška in Jezerska (Mangrtska), z vmesnim grebenom visokogorskih Ponc. Tako se prečno na glavno dolino razteza Rateška pokrajina vse do razvodnega slemena Karavank na eni strani in razvodnega grebena Julijskih Alp na drugi, razmaknjena približno deset 
kilometrov. Od drugih odsekov Zgornje Savske doline, ki pripadajo posameznim naseljem v njej, se Rateška pokrajina razlikuje še po tretji razvodnici, ki pa jo ne omejuje, temveč prečka in sicer v meridianski smeri po pobočju Karavank in grebenu Ponc ter jo razdeli na dva hidrološka oziroma povirna dela. Na vzhodni del, ki pripada Savi in njeni Dolini ter zahodni, ki je sestavni del Belopeške doline, odmaka pa jo nasprotno usmerjena Jezernica $\mathrm{z}$ Belim potokom, odtekajočim $\mathrm{v}$ Ziljico in Ziljo, pritok Drave. Kljub razvodni legi je Rateška pokrajina zaokrožena, kajti dolinski del razvodnice je komaj opazen in prometne povezave Rateč $z$ obema stranskima dolinama sploh ne ovira. Pač pa se je na to razvodnico po prvi svetovni vojni naslonila državna meja med Italijo in takrat nastalo Jugoslavijo, ki je katastrsko občino kratkomalo prepolovila ter $\mathrm{s}$ tem prizadela gospodarsko življenje takrat še povsem agrarnih Rateč. Tudi to je pripomoglo, da je agrarna raba zamejskega dela katastrske občine manj intenzivna kakor tostran meje, kljub dvolastniškemu statusu, ki ga imajo Ratečani.

Za pokrajinske razlike je pomembna že nadmorska višina vseh treh delov pokrajine. Dno glavne doline je $v$ absolutni višini $850-860 \mathrm{~m}$, kar je sicer najnižji in najpoložnejši del pokrajine, vendar pa precej višji od $600 \mathrm{~m}$, kjer se $\mathrm{v}$ naših razmerah začenja hribovsko kmetijstvo. Vseeno pa je najugodnejši, zato je $v$ njem tudi nastalo naselbinsko in drugo jedro pokrajine. Tu so edina obdelovalna tla, ki so agrarni razvoj Rateč sploh omogočila.

Drugi del, ki ga sestavljajo karavanška pobočja, komaj presega 1500 m, zato ostaja precej pod zgornjo gozdno mejo. Rateške Karavanke niso le nižje od drugih Karavank, temveč tudi položnejše, so takorekoč le hribovje. Zato je Ratečanom tudi dostopnejše. Zaradi lege tik nad vasjo so pobočja zanjo posebej pomembna. Med drugim tudi zaradi prisojne lege, gladkega površja in tekočih voda, ki jih omogočajo prepustni paleozojski skrilavci in peščenci, pokriti s sklenjeno preperelinsko odejo. Na njih so zato precej gozda izkrčili (Trebiže), vendar le za pašnike in senožeti, deloma tudi za planine, ne pa za samotne kmetije (kisla tla!). Prav karavanška pobočja so k živinorejski usmejenosti Rateč največ pripomogla.

Tretji, julijski del pokrajine je- sicer najobsežnejši, vendar kmetijsko najmanj pomemben. Tak ni le zaradi severne, osojne lege tega dela Julijskih Alp, temveč tudi zaradi visokogorske razsežnosti, ki se nad zgornjo gozdno mejo, ta je okoli $1900 \mathrm{~m}$ visoko (Lovrenčak 1986), dviga več sto metrov višje, ponekod skoraj tisoč. Golemu, skalnatemu svetu pripada tako več kot petina vsega površja. Razgaljene strmine so marsikje tudi v nižji legi, segajoči do vznožij, obloženimi z melišči. Vse to je hkrati posledica alpske klime in karbonatne sestave Julijskih Alp. Odtod njihova pleistocenska priostrenost $\mathrm{v}$ zgornjih delih ter obilica kvartarnih nanosov $\mathrm{v}$ spodnjih.

Kako malo je rateški del Julijskih Alp kmetijski, kaže že dno obeh stranskih dolin, skratka najnižji svet, ki je celo za pašo le malokje uporaben, sploh pa ne za travnike 
in še manj za orno zemljo, ki je predvsem zaradi pretanke pedološke odeje ni tudi v najnižji, okoli $900 \mathrm{~m}$ visoki legi. Sploh je $\mathrm{v}$ obeh dolinah že zaradi nakopičenih morenskih, meliščnih in hudourniških nanosov premalo gladkih tal (Gams 1992). Še manj jih je seveda višje na pobočjih sicer še gozdnega pasu. Tam pa, kjer naj bi planine v prvi vrsti bile, namreč ob zgornji gozdni meji, jih domala ni. Tako so si mogli Ratečani na julijski strani urediti le dve ali tri planine, ki pa so vse dolinske. Pri tem je Jezerska dolina ugodnejša od Planiške. V njej je pravzaprav edina rateška planina (Za jezerom), ki je za govedo še danes pomembna, čeprav je onstran meje.

\subsection{Klimatske osnove}

Skope osnove za kmetijstvo niso v Rateški pokrajini le posledica njene goratosti, temveč tudi manj ugodnih klimatskih lastnosti, ki pa so z njo, kakor kažejo orografske padavine in temperaturni pasovi, tudi neposredno povezane. Rateška pokrajina, čeprav ni velika, dobiva zelo različno količino padavin, od dobrih $1600 \mathrm{~mm}$ do več kot 2800 (HMZ 1931-1990). Ne kaže pa prezreti, da je meteorološka postaja v Ratečah reprezentativna zgolj za dno glavne doline. To pa je s 1600 do $1700 \mathrm{~mm}$ padavin najmanj namočeno. Toliko so jih deležna tudi obdelovalna tla, ki so v celoti omejena na dno Doline. Senožeti na višjih karavanških pobočjih dobivajo že 1800 do $1900 \mathrm{~mm}$ padavin, medtem ko jih je Sovška planina na slemenu deležna že okoli $2000 \mathrm{~mm}$. Nasprotno pa jih planine na julijski strani prejmejo letno že več kot $2200 \mathrm{~mm}$, čeprav so v Jezerski dolini v precej nižji legi $(900$ do $1100 \mathrm{~m})$. Sploh se na julijski strani padavine $\mathrm{z}$ višino naglo stopnjujejo, saj znašajo horizontalni gradienti okoli 100 $\mathrm{mm} / \mathrm{km}$ in vertikalni tudi do $200 \mathrm{~mm} / 100 \mathrm{~m}$, če namreč sklepamo po izohietah, ki so rekonstruirane glede na orografijo in ustrezne gradiente (Pristov s sod., 1984 ).

Rateška pokrajina je znana po dolgih, mrzlih in tudi snežnih zimah. Srednja letna temperatura zraka je v Ratečah razmeroma zelo nizka, komaj $5,7^{\circ} \mathrm{C}$, medtem ko je povprečna julijska temperatura $15,7^{0}$ in januarska $-4,7^{0}$ (HMZ 1961-1990). Nekaj nad polovico leta, od sredine aprila do druge dekade oktobra, se temperature drže nad $5^{\circ} \mathrm{C}$, kar je za rast travinja in za živinorejsko usmerjeno kmetijstvo osnovnega pomena. $\mathrm{Za}$ njivske kulture pa je pomembno, da trajajo temperature nad $10^{\circ}$ že dober mesec manj, nad $15^{\circ}$ pa le dobra dva meseca, kar opozarja zlasti na težave, ki jih ima kmetijstvo z drugim posevkom.

Mrzle zime in kratka, sveža poletja niso le posledica višje nadmorske lege Rateč, temveč tudi lege znotraj alpskega sveta, obdanega od visokogorskega obrobja. Nekdaj ekstenzivno in avtarkično kmetijstvo je sicer gojilo različne kulture, vendar s precej skromnimi donosi. Gojili so vse vrste žit, razen ajde, največ pa rži. Le v prikladnih legah je dozorela tudi koruza in v ugodnih letih fižol za zrnje. Najbolj pa sta uspevala krompir in zelje. Posebno značilno je, da se je kot drugi posevek obnesla samo repa. 
Razumljivo je, da je bila živinoreja poglavitna kmetijska panoga in tudi edina, ki se je do danes še obdržala, čeprav v precej manjšem obsegu.

\subsection{Raba tal}

Za obravnavano alpsko pokrajino je značilna sestava zemljiških kategorij. Po franciscejskem katastru, ki vključuje celotno katastrsko občino $\left(50,8 \mathrm{~km}^{2}\right), \mathrm{z}$ zamejskim delom vred, je pripadala nerodovitnemu, skalnatemu svetu dobra petina vse površine $(21,5 \%)$, gozdu pa slaba četrtina (24,3\%). Za kmetijsko rabo je ustrezala sicer dobra polovica preostale površine, vendar so zavzemali več kot tretjino pašniki $(37 \%)$ in približno sedmino travniki (13,7\%). Travna odeja je obsegala potemtakem dobro polovico celotne občine, njiv pa je bilo komaj 2,5\%, vsega 129 ha. Na prebivalca, računano za leto 1880 , je prišlo komaj 0,17 ha njivske površine, zato pa več travniške $(0,91$ ha) in zlasti pašniške $(2,48$ ha). Skromne osnove za poljedelstvo in zelo ugodne za živinorejo so več kot očitne.

Če se omejimo na vzhodni del katastrske občine, ki je tostran državne meje, je po podatkih geodetske uprave na Jesenicah njena struktura za leto 1991 naslednja. Dobro polovico vse površine pokriva nerodovitni svet $(50,6 \%)$, gozda pa je manj kot tretjina $(30,6 \%)$. Precej manj je pašnikov $(8,5 \%)$ in še manj travnikov $(6,6 \%)$, medtem ko je njiv manj kot dva odstotka (1,9\%). Vse obdelovalne zemlje ni niti desetina $(8,5 \%)$. Dejansko je niti toliko ni, kajti katastrski podatki niso ažurirani, med travnike pa je štetih tudi del senožeti. Primerjava franciscejskega in sedanjega katastra ne opozarja le na različno pojmovanje posameznih zemljiških kategorij, zlasti nerodovitnega sveta in senožeti, temveč tudi na ogozdovanje in ozelenjevanje kot zelo značilna procesa zadnjih desetletij.

\subsection{Socialna sestava prebivalstva}

Zelo značilna je prebivalstvena preobrazba Rateč. Med 648 prebivalci je bilo leta 1991 aktivnih kmečkih le še desetina $(11 \%)$ in med 206 gospodinjstvi so kmečka le še tri $(1,5 \%)$, pač pa je mešanih kar $47(22,7 \%)$, medtem ko je nekmečkih gospodinjstev daleč največ (157 ali 75,8 \%). To kaže, kako izrazito se je v zadnjih desetletjih uveljavila deagrarizacija Rateč. Značilna je tudi posestna struktura gospodinjstev. Skoraj vso kmetijsko zemljo posedujejo mešana in nekmečka gospodinjstva (s kmečkim gospodarstvom) in na njih sloni celotno kmetijstvo, kajti čista kmečka jo imajo le nekaj odstotkov.

Kljub izraziti deagrarizaciji se število rateških prebivalcev ni bistveno zmanjšalo. V povojnem obdobju je nazadovalo približno za desetino. Vzrok za takšno stanje je iskati $v$ dobri prometni legi naselja oziroma bližini delovnih mest, čeprav so Rateče 
med vsemi dolinskimi naselji najbolj oddaljene od Jesenic, ki so glavno zposlitveno središče celotne Doline. Tja in v Mojstrano se dnevno vozi skoraj sto ljudi, v Kranjsko Goro več kot petdeset in približno prav toliko preko meje v Belo Peč, in tudi v Avstrijo odhaja nekaj ljudi. Vseh dnevnih migrantov je kar 240, v samih Ratečah pa je izven kmetijstva zaposlenih še 38 ljudi, 130 pa je upokojencev. V naselju je tudi nekaj nad 50 turističnih sob z več kot 120 ležišči (KS Rateče 1992). Z gosti povezano delo pa sloni predvsem na gospodinjah, kar pa poklicna statistika ne zajema.

Zaposlitvena struktura Rateč je nasploh pestra. Zaposlitev v industriji je sicer še vedno prevladujoča, čeprav nekoliko nazaduje, vendar sta pomembna tudi terciarni in kvartarni sektor, ki sta v rahlem porastu, medtem ko se je zaposlitev v kmetijstvu bistveno zmanjšala, čeprav ne $v$ tolikšni meri, kakor kaže poklicna statistika. Namesto "zaposlitev v kmetijstvu" bi bil ustreznejši izraz "ukvarjanje s kmetijstvom". To seveda ni zgolj le poklicno delo, temveč predvsem dodatno oziroma vzporedno. In prav na tovrstnem delu sedanje kmetijstvo pravzaprav sloni. Ekonomsko vzeto je današnje rateško kmetijstvo le še dopolnilna gospodarska panoga, poklicno pa niti to skoraj ni več. Čeprav slabi, pa je objektivno še vedno pomembna njegova vloga ohranjanja alpske kulturne pokrajine, kajti zaradi skromne intenzivnosti je kmetijstvo okoljsko še neproblematično, kar je osvetlila tudi raziskava o njegovi energijski intenzivnosti. Pri tem gre $v$ bistvu pravzaprav za živinorejo, ki pa ni specializirana, je hkrati mlečna in mesna.

Tudi zanjo je značilno, čeprav se je še najbolj ohranila, bistveno manjše število živine. Leta 1991 je bilo v Ratečah le še 217 govedi, od tega 140 odrasle živine, medtem ko je prašičereja skoraj zamrla (še 15 prašičev). Več je sicer ovac (406 glav), a glede na nekdanjo čredo je njihovo število še veliko bolj nazadovalo kakor pri govedu. Kako malo je živine, kaže primerjava s kmetijsko površino. Na gospodinjstvo s kmečkim gospodarstvom pridejo povprečno po štiri glave govedi in osem ovac, na hektar kmetijske zemlje pa manj kot dve govedi in manj kot štiri ovce. Nizka živinorejska gostota ne kaže le na zmerno živinorejo, temveč tudi na njeno okoljsko ustreznost. Po zbranih podatkih (anketiranju) naj bi se $\mathrm{v}$ primerjavi s predvojnim stanjem število živine več kot prepolovilo. Zgovoren je podatek, da oddajajo Rateče dnevno le okoli 4501 mleka in letno le okoli $16000 \mathrm{~kg}$ mesa (KS 1992). Četrtina gospodinjstev s kmečkim gospodarstvom pridela zase le dovolj krompirja in del zelenjave, medtem ko vse drugo, razen seveda mleka in mesa, kupujejo. 


\section{ENERGIJSKA INTENZIVNOST KMETIJSTVA}

\section{I. Značilnosti, pomembne za razumevanje energijske gostote}

Vpogled v intenzivnost in strukturo rateškega kmetijstva za leto 1993 sloni na popisu 12 gospodinjstev s kmečkim gospodarstvom, kar je četrtina vseh tovrstnih. Med njimi je tretjina večjih, tretjina srednjih in tretjina manjših. Izbrane kmetije kažejo podobno sestavo zemljiških kategorij, kakršna velja za celotno katastrsko občino. Imeti jih moremo zato za reprezentativne. Zanje je značilno, da so za slovenske razmere nadpovprečno velike. Obsegajo namreč po 28,5 ha, z razponom od 4,5 do 50 ha. Po kmetijski površini pa so precej manjše, velike povprečno po 8,8 ha, vključno s senožetmi. Toda njiv kot najintenzivnejše zemljiške kategorije skoraj ni več. Imajo jih povprečno po komaj 0,36 ha, domala izključno le za lastno pridelavo krompirja.

Pri zemljiških kategorijah so senožeti poleg pašnikov za računanje energijske intenzivnosti kmetij glavna problematika. Uradna satistika jih ne pozna več, anketirane kmetije pa jih imajo povprečno po 3,71 ha, $\mathrm{z}$ razponom od 2,5 do 15 ha. Dejansko uporabljana površina kmetij je tako večja od obdelovalne površine za okoli $13 \%$. Z upoštevanjem skupnih pašnikov pa se ta poveča še za približno $2,6 \%$, skupno torej za več kot $15 \%$. V tem primeru je ustrezneje, da govorimo o kmetijski površini in ne obdelovalni. Del naravnega gnoja in tudi mineralnih gnojil porabijo namreč tudi na senožetih in vaških pašnikih. S tem se seveda zmanjša energijska gostota, ker porabo energije razporedimo na večjo površino. Energijska gostota je zato izračunana na dva načina. Najprej po porabi energije na obdelovalno površino, kakor smo jo računali drugod po Sloveniji (upoštevajoč njive in dvokosne travnike), nato še porabo na kmetijsko površino (še z upoštevanjem senožeti pa tudi vaških pašnikov in planin, in sicer glede na število živine, ki jo posamezne kmetije tam pasejo). Vprašanje pa je, kolikšen del senožetnega sveta dejansko še kosijo, ker se čedalje bolj zarašča. O tem pa ni zanesljivih podatkov. 


\subsection{Stopnja in razpon energijske intenzivnosti kmetij}

Poglavitna značilnost je, da se je rateško kmetijstvo v zadnjih desetletjih strukturno bistveno spremenilo. Iz mešanega živinorejsko-poljedelskega je postalo domala čisto živinorejsko. Hkrati se je intenziviralo, vendar ne pretirano, prej bi rekli, da je zmerno intenzivno. Takšno ni le znotraj alpskega sveta, temveč tudi v primerjavi $\mathrm{z}$ drugimi deli Slovenije. Zaradi njihove obmejne lege in dvolastniške sestave pa je razvoj Rateč nekoliko drugačen od razvoja v drugih delih Zgornje Savske doline.

Tabela: Energijska intenzivnost kmetij* v Ratečah leta 1993

\begin{tabular}{crrrrr}
$\begin{array}{c}\text { Oznaka } \\
\text { kmetije }\end{array}$ & $\begin{array}{c}\text { Skupno } \\
\text { vsi vnosi } \\
\text { v GJ }\end{array}$ & $\begin{array}{c}\text { V GJ/ha } \\
\text { obdel. } \\
\text { površine }\end{array}$ & $\begin{array}{c}\text { V GJ/ha } \\
\text { kmet. } \\
\text { površine } * *\end{array}$ & $\begin{array}{c}\text { Brez } \\
\text { električne } \\
\text { v GJ }\end{array}$ & $\begin{array}{c}\text { energije } \\
\text { obd. površine } \\
\text { v GJ/ha }\end{array}$ \\
\hline 1 & 79,28 & 19,82 & 5,92 & 23,67 & 5,92 \\
2 & 101,84 & 14,55 & 6,08 & 42,54 & 6,08 \\
3 & 73,05 & 16,23 & 3,90 & 17,44 & 3,90 \\
4 & 113,15 & 32,33 & 11,97 & 53,85 & 15,38 \\
5 & 89,09 & 17,84 & 4,46 & 44,57 & 8,91 \\
6 & 111,42 & 46,42 & 22,32 & 55,81 & 22,32 \\
7 & 79,66 & 18,97 & 2,41 & 24,05 & 5,73 \\
8 & 133,37 & 13,75 & 3,61 & 57,77 & 5,96 \\
9 & 56,28 & 12,51 & 2,27 & 22,68 & 5,04 \\
10 & 87,40 & 33,61 & 5,38 & 48,42 & 18,62 \\
11 & 223,36 & 13,54 & 5,88 & 117,52 & 7,12 \\
12 & 203,25 & 11,96 & 4,87 & 97,41 & 5,73 \\
\hline Povprečno & 112,60 & 16,88 & 5,16 & 44,83 & 7,48
\end{tabular}

*Gospodinjstva s kmečkim gospodarstvom (čista kmečka, mešana, nekmečka) **Upoštevana je vsa površina, ne glede na delež opuščenih senožeti

Glede na vso energijo, vloženo v obdelovalno zemljo, dosega energijska gostota preučenih kmetij povprečno $16,9 \mathrm{GJ} / \mathrm{ha}$ in glede na energijo, vloženo $\mathrm{v}$ kmetijsko zemljo, pa 5,2 GJ/ha (glej tabelo). Prvo uvršča rateško kmetijstvo komaj še med intenzivne oziroma med "sodobne nižinske kmetije" tudi po načinih kmetovanja v svetu, kakor ga je razvrstil Slesser. Z ekološkega vidika, ki nas predvsem zanima, pa intenzivnost rateškega kmetijstva komaj presega Slesserjev prag. Glede na večjo občutljivost alpskega okolja, ki ta prag znižuje, ga presega seveda za več. Tako pa je le na prvi pogled, če namreč ne upoštevamo strukture vložene energije. Predno pa jo razčlenimo, si oglejmo, kakšen je energijski obseg obravnavanih kmetij. Skoraj polovica namreč obravnavanega praga ne dosega, kajti njihov energijski razpon je zelo velik. Sega od komaj 11,96 GJ/ha do 46,42 GJ/ha. Razlike med kmetijami so 
torej zelo očitne, skoraj v razmerju 1:4 (brez upoštevanja električne energije skoraj 1:7). Tolikšno neizenačenost tolmačimo predsem kot odraz povojnega razvoja našega kmetijstva, ki se je v socialističnih razmerah razvijalo na poseben način. Tehnološko se je sicer izpopolnjevalo in se tudi po socialni strukturi spreminjalo, vendar ob praktično nespremenjeni posestni sestavi, kar pa je bistveno. Ta je na splošno sicer drobna, vseeno pa različna. Uveljavljeni razvoj se je namreč izognil socialnim pretresom, namreč propadu manjših kmetij in nastanku večjih, kajti v povojnih družbenih razmerah kmetijstvo še zdaleč ni bilo izpostavljeno tržnim oziroma ekonomskim zakonitostim tako, kakor npr v zahodni Evropi. Tej preobrazbi se je naše kmetijstvo domala $v$ celoti izognilo, proces pa je očitno le odrinjen. Odtod je značilna ne le posestna, temveč tudi socialna in ekonomska struktura naših kmetij, ki je zelo različna že po posameznih vaseh. Medtem ko je po porabi skupne energije (brez upoštevanja električne) nekatere kmetije mogoče uvrstiti med primitivne (do 2 $\mathrm{GJ} / \mathrm{ha}$ ), so druge marginalne ( 2 do $5 \mathrm{GJ} / \mathrm{ha}$ ), tretje razvite (5 do $20 \mathrm{GJ} / \mathrm{ha}$ ) in četrte zelo intenzivne (nad $20 \mathrm{GJ} / \mathrm{ha}$ ), če namreč uporabimo klasifikacijo, ki jo je postavil Slesser, ko je prikazal različno intenzivne načine kmetovanja po svetu. Pri tem je značilno, da se razpon, kakršen je v svetovnem obsegu, kaže v slovenskem kmetijstvu že po posameznih vaseh.

\subsection{Energijska struktura kmetij}

Alpski tip kmetijstva, kakršnega predstavljajo Rateče, se tudi energijsko v marsičem razlikuje od tipov, kakršne smo doslej spoznali v drugih delih Slovenije.

Med štirimi skupinami energijskih vnosov (naravni gnoj, mineralna gnojila z zaščitnimi sredstvi, tekoče gorivo, električna energija) je značilno, da odpade v Ratečah na električno energijo več kot polovica vseh vnosov. Ta delež je nesorazmerno velik, kakršen $v$ drugih delih Slovenije ni pogost. Očitno ga ne gre povezati le z alpsko klimo, temveč veliko bolj s tem, da je poraba drugih oblik energije skromnejša, zlasti mineralnih gnojil in zaščitnih sredstev, kar delež električne energije poveča. Če pa delež električne energije, kot ekološko neproblematične, odštejemo, se skupni vnosi bistveno zmanjšajo,s tem pa tudi energijska gostota, ki se zniža pod že omenjeni prag. Zniža se namreč na $7,48 \mathrm{GJ} /$ ha obdelovalne zemlje oziroma na $5,16 \mathrm{GJ} / \mathrm{ha}$ kmetijske. To pa je za dvakrat oziroma trikrat manj od Slesserjevega praga, kar pomeni, da rateško kmetijstvo tudi po tej metodologiji okoljsko nikakor ni sporno. Tako je tudi $v$ primeru, da odštejemo vsaj tretjino senožeti, ki so po približni oceni že opuščene. A to dvigne energijsko gostoto kvečjemu za tretjino, na približno $11 \mathrm{GJ} / \mathrm{ha}$ za obdelovalno zemljo in $7 \mathrm{GJ} / \mathrm{ha}$ za kmetijsko. 
Graf: Energijska struktura kmetij v Ratečah 1993 v \%

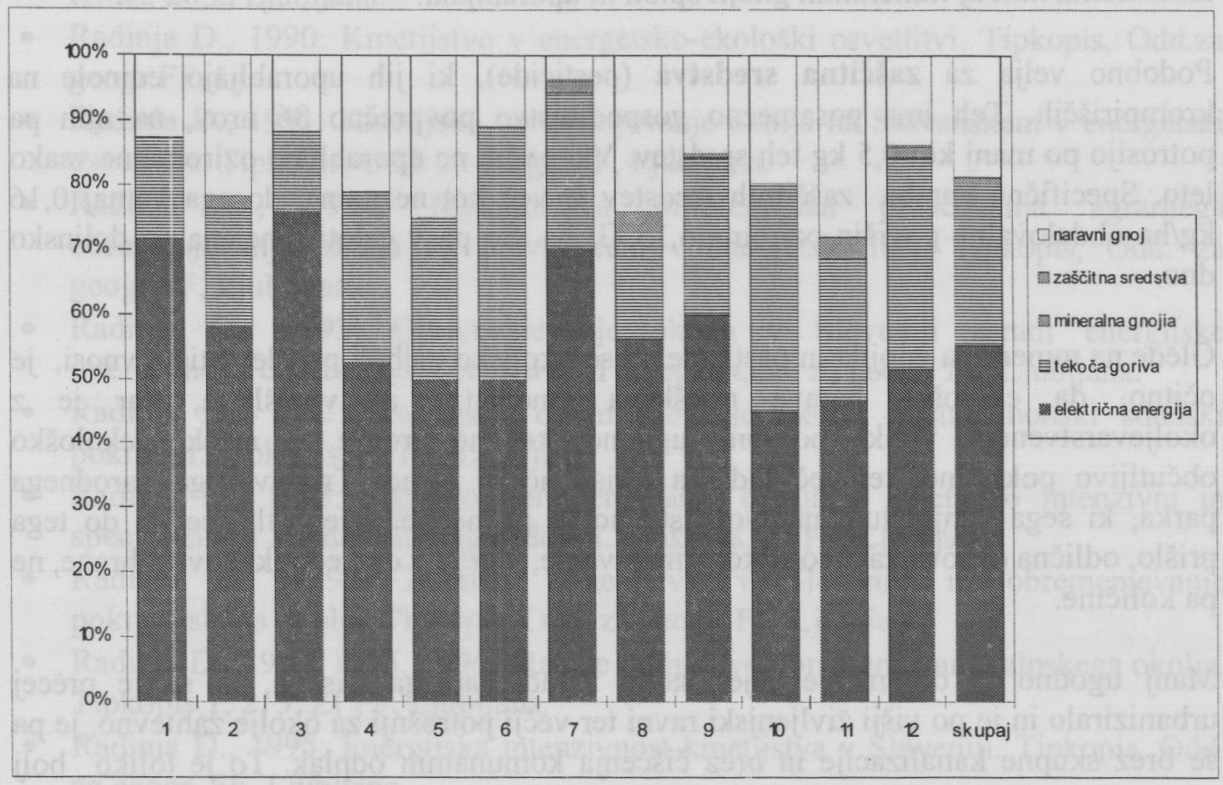

Naslednje, kar je pri strukturi vložene energije pomembno, je delež, ki odpade na naravni gnoj. Povprečno znaša dobro petino vse vložene energije (18,8 \%). Že zaradi razmeroma nizke živinorejske gostote je očitno, da poraba naravnega gnoja okolja ne preobremenjuje in ne more biti vprašljiva. To potrjujejo tudi analize tekoče in talne vode. $\mathrm{V}$ njej so nitrati precej nižji od dopustne koncentracije za pitno vodo, saj praviloma ne presegajo tretjine $\mathrm{MDK}\left(<15 \mathrm{mg} \mathrm{NO}_{3}^{-} / 1\right)$.

Nadalje je značilno, da tudi poraba tekočih goriv na hektar obdelovalne površine ni posebno velika. Povprečno dosega četrtino $(25,1 \%)$ vse porabljene energije. Manjšo porabo povezujemo $\mathrm{z}$ manj intenzivnimi travniki in senožetmi, kajti njiv kot najintenzivnejše zemljiške kategorije domala ni več.

Med posebnostmi rateškega kmetijstva je izredno nizka poraba mineralnih gnojil. Če bi sklepali le po tem, bi rekli, da je docela ekstenzivno. Vzroka za manjšo porabo sta predvsem dva. Njive, ki jih terjajo največ, so domala v celoti opustili, na travnikih pa mineralna gnojila praviloma nadomeščajo $\mathrm{z}$ naravnim gnojem, ki ga je $\mathrm{v}$ živinorejsko usmerjenem kmetijstvu razmeroma veliko. Preučene kmetije so jih porabile le 1500 $\mathrm{kg}$, kar je povprečno po $125 \mathrm{~kg}$ mineralnih gnojil, torej komaj $18,5 \mathrm{~kg}$ na hektar obdelovalne površine oziroma $3,1 \mathrm{GJ} / \mathrm{ha}$, kar ni niti odstotek vse porabljene energije! Specifična poraba je tako nizka, da jo lahko zanemarimo. Nekaj mineralnih gnojil so 
sicer porabili tudi na vaških pašnikih, ki pa tu niso všteta, vendar pa polovica anketiranih kmetij mineralnih gnojil sploh ni uporabljala!

Podobno velja za zašitna sredstva (pesticide), ki jih uporabljajo edinole na krompiriščih. Teh ima posamezno gospodinjstvo povprečno 36 arov, na njih pa potrosijo po manj kot $0,5 \mathrm{~kg}$ teh sredstev. Vsi pa jih ne uporabljajo oziroma ne vsako leto. Specifična poraba zaščitnih sredstev je več kot neznatna, dosega komaj 0,16 $\mathrm{kg} / \mathrm{ha}$ obdelovalne površin oziroma $0,15 \mathrm{GJ} / \mathrm{ha}$. So pa $v$ celoti omejena na dolinsko dno.

Glede na mineralna gnojila in pesticide, ki so okoljsko najbolj problematični vnosi, je očitno, da ekološka narava rateškega kmetijstva ni vprašljiva, kar je $\mathrm{z}$ okoljevarstvenega vidika posebno ugodno, ker ne gre le za alpsko, ekološko občutljivo pokrajino, temveč tudi za turistično in zaradi Triglavskega narodnega parka, ki sega vanjo, tudi naravovarstveno.So pa neonesnažena tla, če bo do tega prišlo, odlična osnova za "biološko" kmetovanje, kjer je v ospredju kakovost hrane, ne pa količine.

Manj ugodno je obremenjevanje okolja zaradi samega naselja, ki se je precej urbaniziralo in je po višji življenjski ravni ter večji potrošnji za okolje zahtevno, je pa še brez skupne kanalizacije in brez čiščenja komunalnih odplak. To je toliko bolj neugodno, ker gre za povirni svet in bližnje zaledje Zelencev, izvira Save Dolinke.

\section{LITERATURA IN VIRI}

- Althaus D., 1984: Die Oekologie des Dorfes. Berlin.

- Bohinec V., 1935: K morfologiji in glaciologiji Rateške pokrajine. Geogr.vest. 11, Ljubljana.

- Gams I., 1992: Prispevek k mladokvartarni geomorfologiji v Zgornjesavski dolini. Geogr. zb.,31, GI SAZU, Ljubljana.

- Lampič B., 1995: Kmetijsko obremenjevanje okolja na Kranjskem polju v energetski osvetlitvi na primeru naselja in katastrske občine Spodnji Brnik. Dipl. nal., Odd. za geogr. FF, Ljubljana.

- Leach G., Slesser M., 1973: Energy Equivalents of Network Inputs to Agriculture, Statclyde University.

- Lovrenčak F., 1986: Zgornja gozdna meja v Julijskih Alpah, Geogr.zb.25, GI SAZU, Ljubljana.

- Melik A., 1954: Slovenski alpski svet, Slov. mat., Ljubljana.

- Petrič M., 1990: Rateče, zgodovina vasi, Kult. in nar. spomeniki Slovenije, Ljubljana. 
- Pristov I., s sod., 1984: Prikaz izdelave vodne bilance na Savi Dolinki, Razprave HMZ, 28,2, Ljubljana.

- Radinja D., 1990: Kmetijstvo v energetsko-ekološki osvetlitvi. Tipkopis, Odd.za geogr.FF, Lj.

- Radinja D., 1991: Kmetijsko obremenjevanje okolja na Slovenskem v energetski osvetlitvi. Tipkopis, Odd. za geogr. FF, Ljubljana.

- Radinja D., 1992: Metodološka problematika preučevanja agrarnega obremenjevanja okolja na Slovenskem v energetski luči. Tipkopis, Odd. za geogr.FF, Ljubljana.

- Radinja D., 1993: Obremenjevanje okolja v Sloveniji zaradi energijske intenzivnosti družbenega kmetijstva. Tipkopis, Odd. za geogr. FF, Ljubljana.

- Radinja D., 1993: Kmetijsko obremenjevanje okolja v subpanonski sotelski pokrajini. Tipkopis, ZI FF, Ljubljana.

- Radinja D., 1993: Agrarno obremenjevanje okolja $\mathrm{v}$ kmetijsko intenzivni in specializirani Spodnji Savinjski dolini. Tipkopis, ZI FF, Ljubljana.

- Radinja D., 1994: Zasebno kmetijstvo v Sloveniji in obremenjevanje pokrajinskega okolja. Tipkopis, Odd. za geogr. FF, Ljubljana.

- Radinja D., 1994, 1995, 1996:, Rateče in njihovo obremenjevanje alpskega okolja. Tipkopis, 1, 2, 3, ZI FF, Ljubljana.

- Radinja D., 1995: Energijska intenzivnost kmetijstva v Sloveniji. Tipkopis, Odd. za geogr. FF, Ljubljana.

- Radinja D., 1996: Kmetijsko obremenjevanje okolja v Spodnjem Podravju s Prlekijo v energijski in nitratni osvetlitvi. Zbornik Sp. Podravje s Prlekijo, 17. zbor.slov. geogr., Ptuj 23. - 26. okt. 1996, Ljubljana.

- Rejec Brancelj I., 1994: Agrarnogeografska problematika Koprskega primorja z vidika varstva okolja. Geographica Slovenica, 26, Ljubljana.

- Sitar M., 1996:, Agrarno obremenjevanje okolja v Deželi v energijski luči na primeru Poljč, Hraš in farme v Poljčah. Dipl. nal., Odd. z geogr. FF, Ljubljana.

- Slesser M., 1975: Energy Requirements of Agriculture; Food, Agriculture and the Environment and Man, 2, Glasgow-London.

- Smrekar A., 1995: Okoljevarstvena problematika agrarne rabe tal na Ljubljanskem barju v energetski osvetlitvi na primeru Črne vasi. Dipl. nal., Odd.za geogr. FF, Ljubljana.

- KS, 1992, Občina Rateče - Planica da ali ne? Krajevna skupnost Rateče. 


\section{A CASE STUDY OF AGRICULTURAL POLLUTION IN SLOVENIAN ALPINE WORLD}

\section{Summary}

A rural settlement, Rateče, with approximately 600 residents, which is located on the bottom of an Alpine valley at the altitude of $860 \mathrm{~m}$, has been typical of intense abandoning of agrarian activities and urbanization in the past few decades. Three quarters of the total 207 households are non-agricultural already now, almost one quarter are mixed, and less than two percent are pure agricultural households. Most of the active population are employed in the nearby settlements, above all in the manufacturing industry, and partly also in the tertiary and quaternary activities, including tourism. Rateče lies in the northwesternmost corner of Slovenia, almost on the meeting point of the three state borders and, thus, about fifty residents daily commute to their jobs to the neighbouring Italy and Austria. Thanks to the favourable transport position and the proximity of jobs, the number of inhabitants has declined by less than a tenth in the post-War period. Thus, the agriculture has become a supplementary economic activity only, and such is also tourism. Due to only moderate natural bases (cooler climate and mountainous landscape), the pure agrarian activity (land cultivation) has been almost completely abandoned, while the animal husbandry has continued in a limited extent.

Since there is only a tenth of active agrarian population, the majority of agriculture is based on mixed households or on the afternoon work in agriculture of those who are regularly employed elsewhere. Besides on the valley bottoms, cultivated lands (meadows) occur only on such locations where machine mowing is feasible, while on more remote and also higher and steeper locations, overgrowing with trees and greening have begun. Besides the mixed households (worker-peasants), it is the mechanization which is the decisive factor granting the continuity of agriculture. Moreover, it is interesting that in the post-War abandoning of agrarian activities accompanied with depopulation and urbanization, the land-ownership structure did not change but remained fragmented. Namely, in the socialist social conditions, farms did not grow larger at the cost of smaller ones. The next characteristic is that the agriculture in this area has become only moderately intensive. Namely, it uses extremely small quantities, also for Slovenian conditions, of mineral fertilizers (30 $\mathrm{kg} / \mathrm{ha})$ and pesticides $(0.16 \mathrm{~kg} / \mathrm{ha})$, and larger quantities of manure and liquid fuels; but it consumes electric energy the most of all.

In the study where the intensity of agriculture was determined on the basis of energy inputs calculated by means of Slesser's (1975) equivalents, it has been established that the total inputs amount to approximately $17 \mathrm{GJ} / \mathrm{ha}$ of agrarian land, but it has been electric energy that has accounted for more than a half of the total consumed energy. Were it deduced from the total sum because it is ecologically non-problematic, the 
enrgy intensity of agriculture amounts only to $7,5 \mathrm{GJ} / \mathrm{ha}$. This is less than the threshold (15 GJ/ha) above which the environmental pollution of individual farms is presumed to spread around. Viewed from this standpoint, the current level of cattle rearing is completely non-problematic, which is also supported by the low level of animal density ( 2 cows and 4 sheep per one hectare of farming land). That the agriculture has not polluted the environment so far is also shown by the analyses of water. Nitrate concentrations in it are considerably lower than the permitted concentrations for drinking water, since they do not, as a rule, exceed one third of the maximum permitted concentration $\left(<15 \mathrm{mg} \mathrm{NO} \mathrm{NO}_{3} / 1\right)$. The existing agriculture is not questionable ecologically but economically. Owing to the hitherto unpolluted environment, there are good competitive possibilities for the biological farming.

Much less favourable is environmental pollution due to the settlement which has already become rather urbanized. By the higher standard of living and greater consumption it is already quite demanding of the environment; besides, it still lacks the common sewage system and sewer treatment. This is, moreover, quite a problem because this is the headwaters' area and the closer catchment area of the Sava source, the central Slovenian river. 